\title{
BRAND LOYALTY DETERMINANTS IN THE CONTEXT OF A SOFT DRINK BRAND
}

\author{
VALTER M. M. FORTES ${ }^{1}$ \\ http://orcid.org/0000-0002-2428-6096 \\ GABRIEL S. MILAN ${ }^{2}$ \\ http://orcid.org/0000-0003-3480-2653 \\ LUCIENE EBERLE \\ (iD) http://orcid.org/0000-0002-0282-5626 \\ DEONIR DE TONI \\ http://orcid.org/0000-0001-9637-8099
}

To cite this paper: Fortes, V. M. M., Milan, G. S., Eberle, L., \& De Toni, D. (2019). Brand loyalty determinants in the context of a soft drink brand. Revista de Administração Mackenzie, 20(5). doi:10.1590/1678-6971/eRAMR190015

Submission: Feb. 3, 2019. Acceptance: May 3, 2019.

\footnotetext{
Instituto de Desenvolvimento Educacional do Alto Uruguai (Faculdade Ideau), Caxias do Sul, RS, Brazil.

2 Universidade do Vale do Rio dos Sinos (Unisinos), São Leopoldo, RS, Brasil.

3 Universidade de Caxias do Sul (UCS), Caxias do Sul, RS, Brazil.
}

\section{(cc) BY This is an open-access article distributed under the terms of the Creative Commons Attribution License.}

\footnotetext{
This paper may be copied, distributed, displayed, transmitted or adapted if provided, in a clear and explicit way, the name of the journal, the edition, the year and the pages on which the paper was originally published, but not suggesting that RAM endorses paper reuse. This licensing term should be made explicit in cases of reuse or distribution to third parties. It is not allowed the use for commercial purposes.

Este artigo pode ser copiado, distribuído, exibido, transmitido ou adaptado desde que citados, de forma clara e explícita, o nome da revista, a edição, o ano e as páginas nas quais o artigo foi publicado originalmente, mas sem sugerir que a RAM endosse a reutilização do artigo. Esse termo de licenciamento deve ser explicitado para os casos de reutilização ou distribuição para terceiros. Não é permitido o uso para fins comerciais.
} 


\section{ABSTRACT}

Purpose: Developing and keeping customers' loyalty in relation to the brand is a strategic requisite for well-succeeded business. Thus, our main purpose was to develop and validate a theoretical model concerning customers brand loyalty.

Originality/value: We explored perceived quality, brand awareness, brand personality, and brand love as brand loyalty determinants. In this sense, the focus of this study was to analyze the impact of some brand loyalty determinant constructs.

Design/methodology/approach: The study was implemented by means of a survey, applied to 284 customers of a soft drink brand from Northeast Brazil that was acquired by one of the biggest soft drink producers in the world. Data were analyzed through multivariate statistics and applying structural equation modeling technic.

Findings: It was possible to evidence that there is a positive relation between the constructs brand awareness and perceived quality and positive influence of brand personality over brand awareness, as well as perceived quality over brand love. Also, evidence showed that brand love influences brand loyalty and that consumption level is a meaningful moderator of this relation.

\section{KEYWORDS}

Perceived quality. Brand awareness. Brand personality. Brand love. Brand loyalty. 


\section{INTRODUCTION}

Brand has achieved a crucial importance in the contemporary market and is taken as a means of establishing strong ties with customers, what can even generate brand loyalty, providing greater profitability, cost-effectiveness and sustainability for companies (Drennan, Bianchi, Cacho-Elizondo, Loreiro, Guibert, \& Teravest, 2015; Pappu \& Quester, 2016; Hegner, Fenko, $\&$ Teravest, 2017). Therefore, several conceptual brand elements have been introduced, as the search for a better understanding of brand personality, customers' awareness in relation to the brands, customers' attitudes in relation to a given brand, brands setting in the market through an adequate positioning and love, that is nourished by customers in relation to a given brand (Maehle \& Shneor, 2010; Zainol, Omar, Osman, \& Habidin, 2016). Specifically, the core of this study is brand loyalty, although some of its determinants have been contemplated, which will be approached later.

According to American Marketing Association - AMA (2017), a brand can be related to buyer experience (customer), and be represented by a set of images or ideas and, in greater part, be associated to a name, symbol, logo, slogan or design. These elements can be developed to represent implicit values, such as ideas or even brand personality. That is why customers use brands to represent stories about their lives and identities, as well as to position themselves in relation to culture, society and other people and social groups (Heding, Knudtzen, \& Bjerre, 2009). More than a name, a brand is the personification of the product and/or service, that is, what it does (benefits it generates for the customer), how it does (or how it generates such benefits for the customer), who does it and how the customer feels by doing it (Pitta \& Franzak, 2008).

The brand can be considered the most valuable asset for any company and has been widely recognized as an essential reason for customers' choices, besides serving as an element to verify differentiation between companies and their offers (product and/or services) and their singularities. In addition, brands can impact customer trust in relation to the companies and their offers and the established trust itself, on its turn, can facilitate the decision making process, attenuating problems associated to the lack or low customer experience in what concerns products and/or services, reducing perceived risks (Huang \& Sarigollu, 2011; Emari, Jafari, \& Mogaddam, 2012; Chung, Lee, \& Heath, 2013).

Brands provide a means of choice for customers, generally taking them to create preferences bonds, revealing an affective emotional behavior 
toward them. This situation constitutes a guarantee and reliable promise of their products and/or services performance in the customer perception (Aaker, 1996). The brand is a source of possible differentiation for a company, product or service in relation to other alternate suppliers and their offers to satisfy the same need, desire, expectation or demand of who consumes it (Aaker, 1996; Ahmad \& Thyagaraj, 2014; Kaufmann, Loureiro, \& Manarioti, 2016; Chinomona, 2016).

According to Aaker (1997), the brand has become an important element, mainly due to the fact that companies are facing a global and competitive market. Many target customers look at a brand that totally joins a variety of values and specific practices. This happens because customers' purchase intention is frequently related to their attitudes and lifestyle (Apaydin \& Köksal, 2011). In this sense, the brand continues to be a potential differentiation alternative according to the features of the market it acts and its positioning facing the competitors. Thus, marketing managers must consider some dimensions related to products and/or services and to other aspects involved in the consumption and purchase decision process, which are vital for their market positioning, and may generate favorable, positive and strong associations, resulting in a single brand in the customers' mind (Loureiro, 2013; Giovanis, 2016; Bairrada, Coelho, \& Coelho, 2018).

In more globalized markets, companies need to build brands that have appeal for global customers, even if their purchase decisions are national, regional or local (Borzooei \& Asgari, 2013). Customers can evaluate similar or identical products and/or services and perform an effective distinction among them, depending on how brands are perceived among themselves, comparatively, what corroborates to the need of greater care with the brand positioning in customers' minds (Keller, 2003). Brands aggregate value to companies offers and give sense to the consumption and purchase decision process, having in mind the value that is perceived by customers or by the market as a whole. Brand value is, basically, the customers' perception on what concerns the value relative to it in terms of a greater association to items like quality, reliability, greater awareness, aggregate value and potential incidence or increase of customer loyalty (Sasmita \& Suki, 2015; Pappu \& Quester, 2016; Wu \& Anridho, 2016). This means that customers choose products and services and their associated brands, not just due to their utilitarian benefits, but also to their symbolic ones (Albert \& Merunka, 2013; Bairrada et al., 2018).

It is common that brands have deep meanings and serve to build a "selfconcept" and an identity in customers, which desire to present to others or 
even aim to reach their individual identity objectives or in terms of insertion in certain social groups according to the brand they choose to consume (MacCraken, 1989). The self-concept is formed from elements of a variety of the individual/customer existence fields (corporal image, the culture they belong to, beliefs, religion, and others). Customers' point of view can be understood as the image they have of themselves and the way they express their identity, based on their self-perception, self-communication, self-motivation, self-control and self-evaluation activities (Burns, 1986). Thus, brands act as social signs, and there is relative congruence between the chosen brand and its user (the customer) or self-image itself, that is considered as a key motivational factor for customers' choices and preferences (Maehle \& Shneor, 2010; Kavaratzis \& Hatch, 2013).

This way, brands help define customers' lives and develop a core role in people's buying behavior and/or consumption, bonding customers and their favorite brands, in such way that some of them can evolve to a real cult to the brands; putting it in another way, to develop an extreme devotion in the direction of one or more specific brands in relation to others (Belk \& Tumbat, 2005). Previous researches verified that when studying customers' relations with brands we should consider that people's memories are organized in a set of nodes and connections. A brand's name is considered a node and the connections are functional associations (utilitarian) or emotional (symbolic or even hedonic) that customers have in their memories concerning them. Then, when a node is activated the associations or relations among the others also become active by means of a set of connections, which are based on information, knowledge or previous experiences (Erdogmus \& BüdeyriTuran, 2012).

The customer that has a positive perception in relation to a given brand will be inclined to develop a greater will or predisposition of buying it, usually proactively seeking for the product or service attached to it (Raska \& Saw, 2012; Won-Moo Hur, Hanna, \& Joon, 2016; Chang \& Jai, 2015). Usually, brand growth is generated by loyal customers or clients, which also ends up encouraging other potential clients or customers, by incurring in positive word-of-mouth, to become effective buyers and, eventually, loyal to the brand. Such situation may occur due to the user personal satisfaction or based on the belief that the brand will provide substantial or superior benefits compared to alternate brands (Alloza, 2008; Schultz \& Block, 2015).

In this sense, it appears that brand loyalty is a key element of interest for researchers and marketing professionals. In fact, it is a concept that has gained much relevance in recent decades. Accordingly, achieving customer 
loyalty in relation to the brand has become a key objective for companies facing an increasingly competitive market (Khan, Rahman, \& Fatma, 2016; Chinomona, 2016).

Considering the exposed, the purpose of this research is to develop and validate a theoretical model concerning customers brand loyalty, contemplating some determinants constructs, being them: perceived quality (Drennan et al., 2015), brand awareness (Sasmita \& Suki, 2015; Thaichon \& Quach, 2015; Molinillo, Japutra, Nguyen, \& Chen, 2017), brand personality (Aaker, 1996, 1997; Clemenz, Brettel, \& Moeller, 2012; Roy, Kahndeparkar \& Motiani, 2016), brand love (Carroll \& Ahuvia, 2006; Roy, Khandeparkar, \& Motiani, 2016; Bairrada et al., 2018) and brand loyalty (Erdogmus \& BüdeyriTuran, 2012; Molinillo et al., 2017), which emphasize a relational understanding between the brand and customers (Aaker, 1997; Drennan et al., 2015).

Briefly presented, the constructs that were contemplated and will be better-approached latter, it is relevant to highlight the context for this investigation. That said, the research target population has involved soft drink customers of the brand Guaraná Jesus, that is consumed mainly by the population of the State of Maranhão, in Brazil, and is in the market for over 80 years. Created by the pharmacist Jesus Norberto Gomes, the brand is, nowadays, a property of The Coca-Cola Company, second place in the regional market, ahead of other brands from the company like, for example, Fanta, Sprite and Guaraná Kuat.

\section{THEORETICAL FRAMEWORK AND RESEARCH HYPOTHESIS}

Firstly, with regard to the proposed theoretical model, it should be noted that the starting point was the understanding of the relationship between the determinants of brand loyalty. The tested model provided a nomological structure of the constructs that form the continuity of relationships with a given brand.

The literature concerning the theorization about brands has centered around the relation customer-brand, based on a metaphor that suggests that the customers create relations with brands the same way they create relations in a social context (Loureiro, 2013). However, a clear conceptual comprehension about customer-brand relations development requires the integration of both attitudinal and behavioral aspects in a predefined order to reflect the development and flux of events in the relation customer-brand, establishing 
satisfactory results for both parties (company and customer) (He, Li, \& Harris, 2012; Sreejesh, Roy, \& Sarkar, 2016).

In the context of this relationship of building evolutionary process between companies and customers, the brand does not represent just a simple name, term, signal, symbol, drawing or a combination of these elements (Kaufmann, Loureiro, Basile, \& Vrontis, 2012). In fact, brands develop a primordial role for customers in the formation of their identity and establish an emotional connection with them (Malär, Krohmer, Hoyer, \& Nyffenegger, 2011). Customers tend to build relationships with brands which are compatible with their own personality (Molinillo et al., 2017). The brand has become an experience (Prahalad \& Ramaswamy, 2004), and the construction of strong, renowned and admirable brands has been transforming in one of the main research objectives of marketing professionals. In this sense, it is stressed that the marketing scenario has changed in the last two decades, because customers are no longer messages or companies content passive receptors and are now actively involved in interactive relationships with a great part of companies and their brands (Kaufmann et al., 2012; Limpasirisuwan \& Donkwa, 2017).

That said, the first construct tested was brand awareness, that is related to the knowledge or recognition that customers have about a brand (and its products and/or services) (Thaichon \& Quach, 2015), that is, how customers associate the brand with the specific product that they intend to buy or consume (Sasmita \& Suki, 2015). In the same reasoning line, Keller (2008) comments that brand awareness comprehends what customers can remember or recognize in a specific brand, or simply if the customers know, or not, such brand. This aspect provides a kind of learning advantage for the brand, affecting customer decision making.

It is understood by brand awareness the capacity that a customer has in recognizing or remembering a brand and associate it to its categories or products and/or services lines, while perceived quality concerns the way customers judge a product and/or service global excellence (Pappu \& Quester, 2006). According to Kan (2002), the higher the level of brand awareness, the higher customers quality evaluation, that is, their perceived quality tends to be greater or elevated.

As to the perceived quality, it is conceptualized as the customer judgment about a product and/or service general excellence or superiority in relation to the competitor offerings (Zeithaml, 1988), based on each individual subjective perceptions (Erdogmus \& Büdeyri-Turan, 2012). Customers perceived quality relative to a product and/or service is considered as an 
essential determinant in building their loyalty in relation to the brand (Pan, Sheng, \& Xie, 2012; Akdeniz, Calantone, \& Voorhees, 2014).

For Rubio, Oubiña, and Villaseñor (2014), brand awareness encourages perceived quality associated with the brand and, therefore, also its eventual credibility in the market due to the smaller perception of functional risk. However, the most conscious customers about a brand are more prone to perceive eventual functionality fails and, consequently, possible attributions of quality lack. Another element that conditions a product and/or service quality perception is the brand name itself, which can be considered as a causal association that many customers do between the recognized brand and the quality induced by brand awareness (Clemenz et al., 2012; Lu, Chang, \& Chang, 2014). When the objective quality of an offer is difficult to be justified or understood, customers can appeal to more abstract signs, reinforcing the importance of strong and well market positioned brands (Perera \& Dissanayake, 2013).

It is observed that brand awareness can be a predictor of brand perception, which involves customers perceived quality. Other researches verify that brand awareness has a positive influence on perceived quality, and the greater brand awareness, the greater the quality customers perceive in their products and/or services (Chi, Yeh, \& Yang, 2009; Sasmita \& Suki, 2015; Wu \& Anridho, 2016). For so, the first research hypothesis emerges:

- H1: Brand awareness positively influences customer perceived quality.

Another brand loyalty determinant considered in the study was brand personality, that is another important customer behavior booster in a variety of contexts. It is understood by brand personality a set of "human" characteristics associated with the brand (Aaker, 1997; Aggarwal \& McGill, 2012; Loureiro, 2013). In other words, its symbolic or self-expressive function easily allows customers to associate human personality traits with the brand. This way, brand personality tends to generate the perception of symbolic benefits by the customer that goes from social approval to social and self-esteem expression (Keller, 1993).

Brand personality is an inanimate object and associated to personality lines resulting from the interactions the customer has with the brand and tends to have a symbolic function and a self-expression format (Bouhlel, Mzoughi, Hadiji, \& Ben, 2009). Thereby, it can represent one of the main components of a brand, along with physical attributes or elements, functional characteristics or benefits inherent to a brand adoption (Maehle \& Shneor, 2010). It is important noting that a brand personification also includes 
aspects connected to gender, age, socioeconomic class and psychographic and emotional characteristics that can be an efficient way to understand a brand performance and value aggregation within a certain target public with specific profiles (Gordon, Zainuddin, \& Magee, 2016; Roy et al., 2016).

With competition intensification, brands innovation and the known personality effects about behavior in general, the interest concerning the symbolic meaning of human traits that customers attribute to brands as a result of emotional or affective connections with them has been stimulated (Rojas-Méndez, Murphy, \& Papadopoulos, 2013; Ha \& Janda, 2014; Gordon et al., 2016; Ahmad \& Thyagaraj, 2017).

A review of works in this subject reveals a positive relation between brand personality and brand awareness, stressing that both constructs are considered essential for brand loyalty construction within customers (Sun \& Tong, 2015; Wu \& Anridho, 2016; Molinillo et al., 2017). Besides, brand personality, as the promoter of brand awareness, can equally affect the customer ability to recognize or recall a brand and associate it to its products and/or service category (Ahmad \& Thyagaraj, 2014; Su \& Tong, 2015; Molinillo et al., 2017). Based on the exposed, the second research hypothesis is presented:

- H2: Brand personality positively influences customer brand awareness.

Customers can evaluate the product more favorably if they realize that the selected brand personality or their preference in brand resembles the ones they appreciate the most (Nikhashemi, Valaei, \& Tarofder, 2017). It is attested that brand personality is considered a prominent construct that predicts customers' preferences and choices and it is crucial for choosing a brand, for the probability of purchasing or repurchasing it and, lastly, for brand success in the market (Aaker, 1997).

Other studies have evidenced that, while brand personality performs a critical role in customer perception comprehension concerning the brand and its products and/or services, in quality instance, customers are more prone to consider a product and/or service quality as an intrinsic feature, and when customers identify and recognize brand personality traits, such features (or traits) will help them form judgments about the single experience provided by the brand and, this way, will affect perceived quality (Ahn, Lee, \& Jeon, 2009; Ha \& Janda, 2014; Nikhashemi et al., 2017).

According to Beldona and Wysong (2007), and Clemenz, Brettel, and Moeller (2012), the more brand personality corresponds to customers' personality, the greater perceived quality of products and/or service that 
take its name (brand) will be. In this sense, the third research hypothesis emerges:

- H3: Brand personality positively influences customers perceived quality.

Brands are omnipresent in customers' daily lives (Albert, Merunka, \& Valette-Florence, 2008). Recent researches sought to understand and explain the kind of relations that customers develop with brands. The great part of the researches about brand love has begun with interpersonal love theory and was applied to customer behavior.

Brand love, therefore, refers to customers love for brands, products and/ or services. Consequently, it is understood as the degree of emotional connection and the passion level that the customer holds in relation to a certain brand (Carroll \& Ahuvia, 2006). It is also highlighted that it tends to be higher for products and/or services that provide symbolic and hedonic benefits (Drennan et al., 2015; Rauschnabel, Krey, Babin, \& Ivens, 2016).

From that, studies converge to the approximation of the constructs brand personality and brand love (Anggraeni \& Rachmanita, 2015; Roy et al., 2016; Hegner et al., 2017). Theories that investigate this relation in the context of customers and their preferred brands, many times, are based on the supposition that customers attribute human traits to brands (Rauschnabel et al., 2016; Hegner et al., 2017) in a process called anthropomorphism (Aggarwal \& McGill, 2012). Therefore, brand personality is attributed and formed by human personality features and/or characters associated to brands, allowing its buyers or users to express themselves through them and what they represent (Anggraeni \& Rachmanita, 2015).

Customer love in relation to a brand is greater for brands that develop a meaningful role in forming customer identity (Loureiro, Kaufmann, \& Demetris, 2012). For so, the authors suggest that an adequate brand personality increases customers willing and predisposition in investing in long term brands relationships (Aaker, 1997; Keller, 2003; Roy et al., 2016). Facing the exposed, the fourth research hypothesis is proposed:

- H4: Brand personality positively influences brand love.

According to Sarkar (2014), during decades researchers have studied customers' attitude facing brands, and have evolved a variety of useful concepts, such as customer satisfaction and brand loyalty. In the last years, researches have demonstrated an increase in the interest about customers' emotions when relating to brands and in the ludic, sensorial and emotional consumption, seeking to understand customer behavior about irrational 
purchase decision in place of the initial domain vision of rational choice, substantiated in the merely utilitarian and transactional decision.

One key issue for marketing theory and practice in the last decades' concerns to brand loyalty construction, maintenance, and development, in which companies aim to obtain a sustainable competitive advantage, considering that marketing environment is dynamic and has an aggressive competition. For this reason, brand loyalty is considered essential for any company that intends to obtain long term satisfactory market and economic performance (Moisescu \& Allen, 2010; Limpasirisuwan \& Donkwa, 2017; Molinillo et al., 2017; Vera \& Trujillo, 2017).

When empirically analyzing brand love relations with other constructs, more specifically, brand personality and brand loyalty, Roy et al. (2016) evidenced that brand love is an antecedent that positively affects brand loyalty. Such authors add, still, that greater part of the reference studies concerning brands highlight that brand loyalty is a result of brand love that customers feel, what is reinforced by other authors (Carroll \& Ahuvia, 2006; Roy et al., 2016; Limpasirisuwan \& Donkwa, 2017). Considering the presented arguments, it is stressed brand loyalty importance, as well as brand love, in narrowing the relations between customers and a brand. This way, the fifth research hypothesis has been formulated:

- H5: Brand love positively influences customer brand loyalty.

Finally, it will also be tested if consumption level presents a moderator effect in the relationship between customer brand love and brand loyalty. Customers beliefs or associations about the brand come from consistent attributes (Clemenz et al., 2012), not only from the brand experience but also from the customer evaluation to any direct and/or indirect contact with the brand and its products and/or services (Keller, 1993). This way, the sixth research hypothesis has been formulated:

- H6: Analyze the moderator effect of consumption level in the relation between brand love and loyalty.

Aiming at providing a better understanding of the proposed theoretical model and its respective hypotheses, Figure 2.1 is presented: 


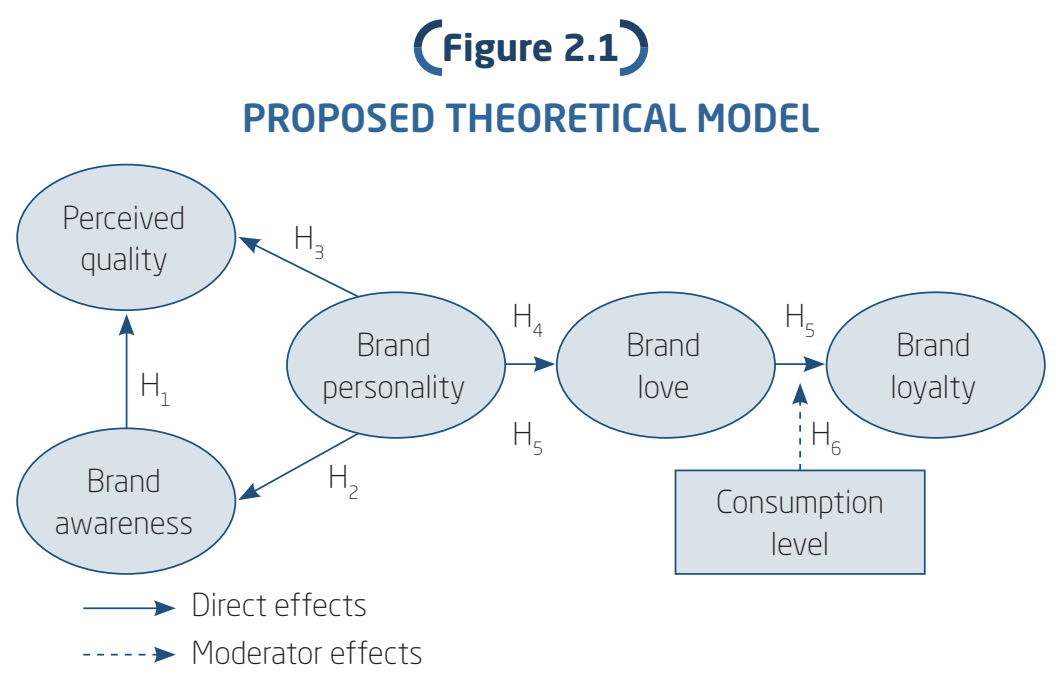

Source: Elaborated by the authors.

\section{RESEARCH METHOD}

Related to the research, we performed a descriptive quantitative method, based on a structured data collection with the application of a survey, crosssectional, applied to a sample based on a structured questionnaire (Hair, Black, Babin, \& Anderson, 2010; Fink, 2013). Data analysis was performed using structural equation modeling technic, which is considered as an extension of various techniques and multivariate procedures (Kline, 2011; Byrne, 2016).

In this sense, the study was performed from the perspective of local customers of the Brazilian soft drink. To evaluate the proposed theoretical model , that is, the determinants of brand loyalty from the referred product, it was considered the fact that the population knows or has a strong bonding with the brand and the product chosen for this investigation, that has an estimated population of 1,091,868 inhabitants (Instituto Brasileiro de Geografia e Estatística, 2018). Sample selection was performed based on a non-probabilistic sample, by convenience (Malhotra, Birks, \& Wills, 2012).

To measure the constructs from the chosen scales, it was opted by using a seven-point Likert scale, where the extremes varied from 1 ("totally disagree") to 7 ("totally agree"). It is stressed that this kind of scale has proven its applicability in a variety of research environments, including some related to brand loyalty context (Das, 2014; Khan \& Rahman, 2016). 
As for the investigated constructs operationalization, their respective scales are presented in Figure 3.1:

\section{(Figure 3.1)}

\section{CONSTRUCTS OPERATIONALIZATION}

\begin{tabular}{llcl}
\hline \multicolumn{1}{c}{ Constructs } & Variable labels & $\begin{array}{c}\text { Scale items } \\
\text { number }\end{array}$ & Authors \\
\hline Brand awareness & BR_AWAR_1 to 4 & 04 & Yoo, Donthu, and Lee (2000) \\
\hline Perceived quality & PERC_QUA_1 to 3 & 03 & Yoo, Donthu, and Lee (2000) \\
\hline Brand personality & BR_PERS_1 to 5 & 05 & $\begin{array}{l}\text { Adapted from Aaker (1997) } \\
\text { and Phau and Lau (2000) }\end{array}$ \\
\hline Brand love & BR_LOVE_1 to 10 & 10 & Carroll and Ahuvia (2006) \\
\hline Brand loyalty & BR_LOY_1 to 3 & 03 & Yoo, Donthu, and Lee (2000) \\
\hline
\end{tabular}

Source: Elaborated by the authors.

We opted for the direct form of data collection approach, which was conducted between September and October 2017, and data was mainly collected in Universidade Federal do Maranhão (UFMA - Federal University of Maranhão) campus, where there was access to students and administrative staff of the institution for the research purpose, by using the self-completion method (Fink, 2013).

Before analyzing the survey data, it was necessary to prepare them with the intention of detecting typing errors, missing data and outliers (atypical observations) (Davey \& Savla, 2010). In the case of missing data, it was used the listwise deletion technique (Hair et al., 2010), for which only the questionnaires with complete data were considered, and 15 questionnaires were eliminated, coming to a total of 285 valid cases.

The next step was the verification of outliers. For that purpose, a combination of univariate and multivariate analysis was used (Malhotra et al., 2012). First, atypical univariate observations were detected by checking the standard scores (Z-scores) that showed values higher than $|3|$ (Hair et al., 2010), in which one case was eliminated. Multivariate outliers by calculating the Mahalanobis distance were also identified $\left(\mathrm{D}^{2}, \mathrm{p}<0.005\right)$, considering the values with rates up to $3\left(\mathrm{D}^{2} / \mathrm{gl}\right.$ ) (Hair et al., 2010; Tabachnick \& Fidell, 2012). In this sense, no multivariate atypical observation was found, resulting in a final sample of 284 valid cases. 


\section{RESULTS PRESENTATION}

\subsection{Sample characterization}

Final sample resulted in 284 valid cases (gender: male: 138 and female: 146; $76 \%$ with an average age between 18 and 25 years old). When questioned about Guaraná Jesus brand soft drink consumption frequency, it was verified that the greater part of the respondents consumes the product daily. In numbers, this means that $71.5 \%$ (203 respondents) consume Guaraná Jesus daily, $18 \%$ (51 respondents) two to three times a week, and 7.4\% (21 respondents) once a week. The other respondents affirm to consume Guaraná Jesus once a month or rarely.

\subsection{Constructs individual validation}

The intention of individually validating the constructs is to validate the model integrated with its respective constructs (Hair et al., 2010; Kline, 2011). For the individual validation of the constructs, the unidimensionality, reliability, convergent validity, and discriminant validity were analyzed. To verify the unidimensionality of the constructs, we proceed with the exploratory factor analysis (EFA) through principal components and by means of the Varimax orthogonal rotation, being the factor loads of EFA considered satisfactory, because they presented values above 0.50 , which is considered very good (Hair et al., 2010). Furthermore, the values of the explained variance showed a minimum value of $70.50 \%(0.705)$. It was also verified that the Cronbach's alpha and the composite reliability showed minimum values of 0.630 and 0.810 , where values higher than or equal to 0.70 are suggested or higher than 0.6 (Hair et al., 2010; Malhotra et al., 2012).

Then, the convergent validity of the constructs was calculated through confirmatory factor analysis (CFA), considering the parameters as values above 0.5 (Kline, 2011; Byrne, 2016), as shown in Figure 4.2.1. 


\section{(Figure 4.2.1)}

CRONBACH'S ALPHA, COMPOSITE RELIABILITY, AND EXTRACTED VARIANCE

\begin{tabular}{lccc}
\hline \multicolumn{1}{c}{ Constructs } & $\begin{array}{c}\text { Cronbach's } \\
\text { alpha }\end{array}$ & $\begin{array}{c}\text { Composite } \\
\text { reliability }\end{array}$ & Extracted variance \\
\hline Perceived quality & 0.90 & 0.94 & 0.85 \\
\hline Brand awareness & 0.63 & 0.84 & 0.58 \\
\hline Brand personality & 0.90 & 0.91 & 0.67 \\
\hline Brand love & 0.80 & 0.96 & 0.74 \\
\hline Brand loyalty & 0.71 & 0.81 & 0.61 \\
\hline
\end{tabular}

Source: Elaborated by the authors.

After this, the discriminant validity was verified by calculating the shared variances, considering the method proposed by Fornell and Larcker (1981), calculating the squared correlations between the constructs, taking into account that the variances extracted from the constructs are compared to the shared variances, as shown in Figure 4.2.2. The results showed adequate discriminant validity between the constructs.

(Figure 4.2.2)

DISCRIMINANT VALIDITY

\begin{tabular}{lccccc}
\multicolumn{1}{c}{ Constructs } & $\begin{array}{c}\text { Perceived } \\
\text { quality }\end{array}$ & $\begin{array}{c}\text { Brand } \\
\text { awareness }\end{array}$ & $\begin{array}{c}\text { Brand } \\
\text { personality }\end{array}$ & $\begin{array}{c}\text { Brand } \\
\text { love }\end{array}$ & $\begin{array}{c}\text { Brand } \\
\text { loyalty }\end{array}$ \\
\hline Perceived quality & 0.856 & & & & \\
\hline Brand awareness & 0.627 & 0.576 & & & \\
\hline Brand personality & 0.219 & 0.220 & 0.519 & & \\
\hline Brand love & 0.416 & 0.334 & 0.497 & 0.740 & \\
\hline Brand loyalty & 0.233 & 0.248 & 0.321 & 0.612 & 0.609 \\
\hline
\end{tabular}

Source: Elaborated by the authors. 


\subsection{Theoretical and structural model validation}

To evaluate the general model fit of the proposed theoretical model and verify if it has adequate representation of the tested relationships, three goodness-of-model fit measures were used, based on the classification of Hair et al. (2010): absolute measure fit (GFI and RMSEA = values between 0.05 and 0.08 are acceptable), incremental measure fit (AGFI, TLI, and NFI) and moderated measure fit (CFI), where values equal to or higher than 0.90 are considered good indexes.

According to Figure 4.3.1, except for the AGFI, that presented value slightly under the recommended in the literature $(\geq 0.90)$, it is noted that the goodness-of-model fit measures have presented the satisfactory result to support the proposed structural theory. The AGFI value $(0.861)$ is in the cut-off zone, superior to 0.800 and, then, can be accepted (Bagozzi \& Yi, 2012; Grubor, Djokic, \& Milovanov, 2017), having performed lesser than other measures (Figure 4.3.1).

(Figure 4.3.1)

MODEL FIT MEASURES

\begin{tabular}{cc}
\hline Model fit measures & Values \\
\hline GFI & 0.900 \\
\hline AGFI & 0.861 \\
\hline RMSEA & 0.052 \\
\hline AGFI & 0.861 \\
\hline TLI & 0.953 \\
\hline NFI & 0.919 \\
\hline CFI & 0.963
\end{tabular}

Source: Elaborated by the authors.

To test the proposed theoretical model hypotheses, it was verified the significance and magnitude of the regression coefficients, by means of path analysis, the non-patronized coefficients (b), standard errors, pattern coefficients $(\beta)$, t-values, and probabilities, as shown in Figure 4.3.2. 


\section{(Figure 4.3.2)}

HYPOTHESES TESTING

\begin{tabular}{clcccccc}
\hline Hi & Path analysis & b & Error & $\beta$ & $t$-values & $P$ & Results \\
\hline H1 & BR_AWAR $\rightarrow$ PERC_QUA & 0.657 & 0.186 & 0.240 & 3.524 & $p<0.001$ & Supported \\
\hline H2 & BR_PERS $\rightarrow$ BR_AWAR & 0.281 & 0.043 & 0.663 & 6.511 & $p<0.001$ & Supported \\
\hline H3 & BR_PERS $\rightarrow$ PERC_QUA & 0.769 & 0.769 & 0.665 & 8.616 & $p<0.001$ & Supported \\
\hline H4 & BR_PERS $\rightarrow$ BR_LOVE & 1.177 & 0.097 & 0.812 & 12.170 & $p<0.001$ & Supported \\
\hline H5 & BR_LOVE $\rightarrow$ BR_LOY & 0.311 & 0.055 & 0.695 & 5.623 & $p<0.001$ & Supported \\
\hline
\end{tabular}

Significance level: 0.05 .

According to the results, the six research hypotheses were statistically supported, being them: $\mathrm{H} 1$ ("Brand awareness positively influences customer perceived quality”, $\beta=0.240$, $p<0.001$ ), result found by Rubio et al. (2014) and Sasmita and Suki (2015); H2 ("Brand personality positively influences customer brand awareness", $\beta=0.663, p<0.001)$, convergent with Su and Tong's (2015) study; H3 ("Brand personality positively influences customers perceived quality", $\beta=0.655, \mathrm{p}<0.001$ ), confirming the results found by Nikhashemi et al. (2017); H4 ("Brand personality positively influences brand love", $\beta=0.812, p<0,001$ ), confirming Dagger and David (2012) and Anggraeni and Rachmanita's (2015) results; and H5 ("Brand love positively influences customer brand loyalty", $\beta=0.695$, $p<0,001$ ), as pointed out by Carroll and Ahuvia (2006).

Additionally, the determination coefficient $\left(\mathrm{R}^{2}\right)$ was analyzed to verify the hypotheses test effectiveness. For so, in Figure 4.3.3, the determination coefficients $\left(\mathrm{R}^{2}\right)$ resulting from the theoretical model are presented (Hair et al., 2010; Tabachnick \& Fidell, 2012).

\section{(Figure 4.3.3)}

\section{DETERMINATION COEFFICIENTS $\left(\mathrm{R}^{2}\right)$}

\begin{tabular}{cc}
\hline \multicolumn{1}{c}{ Constructs } & Determination coefficient \\
\hline Brand awareness & 0.439 \\
\hline Perceived quality & 0.711 \\
\hline Brand love & 0.659 \\
\hline Brand loyalty & 0.614 \\
\hline
\end{tabular}


Based on data presented in Figure 4.3.3, the determinants (or antecedents) of customers brand loyalty of the soft drink Guaraná Jesus have presented a determination coefficient $\left(\mathrm{R}^{2}\right)$ of 0.614 , that is, $61.4 \%$ of brand loyalty of the soft drink investigated (Guaraná Jesus) can be explained by its determinant constructs (perceived quality, brand awareness, brand personality, and brand love). This result is high explanatory power to the constructs tested in the model (Tabachnick \& Fidell, 2012).

\subsection{The moderator effect of consumption frequency level}

The moderator effect of consumption frequency level was performed through multi-group structural equation modeling, splitting the sample into two groups, being the high level compared to the low level. For so, the comparative tests between groups were performed, by means of the Critical Ratios for Differences between Parameters. It was considered the one indicated by Preacher and Hayes (2004), in which the differences between the groups with Z-scores must be superior to \pm 1.96 , which indicates a significance level lower than 0.05 (p-value $<0.05$ ) and 95\% reliability.

Regarding the level of consumption, respondents were investigated on the frequency of consumption, taking into account daily, weekly, annual or rare consumption. To this end, the sample was separated once again into two groups: 1. high consumption frequency level, every day; and 2. low consumption frequency level, weekly, annually or rarely.

In the moderation test, the moderator effect of the respondents' consumption frequency level was analyzed. When it comes to hypothesis $\mathrm{H6}$, daily consumption frequency has evidenced to be moderated in relation to brand love and brand loyalty $(\mathrm{p}<0.05)$, presenting a Z-score $=-2.128$. It is worth noting that the results point that the relation between brand love and brand loyalty is significantly stronger when the consumption happens every day, positively moderating the relation between constructs ( $\beta$ high level $=0.672$ versus $\beta$ low level $=0.490$ ) (Figure 4.4 .1 ). 


\section{(Figure 4.4.1)}

MODERATOR EFFECT OF CONSUMPTION FREQUENCY LEVEL

\begin{tabular}{|c|c|c|c|c|c|c|c|}
\hline Path analysis & $\begin{array}{c}\text { Consumption } \\
\text { level }\end{array}$ & b & Error & $\beta$ & $t$-values & $p$ & Z-scores \\
\hline \multirow{2}{*}{ BR_LOVE $\rightarrow$ BR_LOY } & High level & 0.563 & 0.059 & 0.672 & 9.822 & $p<0.001$ & \multirow{2}{*}{-2.128} \\
\hline & Low level & 0.323 & 0.095 & 0.490 & 3.526 & $p=0.001$ & \\
\hline
\end{tabular}

Z-Scores > 1.96 .

Source: Elaborated by the authors.

\section{CONCLUSION}

The objective of the study was to understand the factors that determinate customer brand loyalty, which has been an important research agenda in the last decades, generating great academic and managerial interest, overall due to companies' market implications. In this sense, this study contributes to understanding the reasons that determinate such phenomenon, that is, brand loyalty.

The sequential chaining of the constructs demonstrates that, in a theoretical perspective, brand awareness is assumed as the ability a customer has in recognizing or remembering a brand and associate it to its product and/or service category (Keller, 2008; Lee \& Jee, 2016) and perceived quality as a result of the comparison of customer expectations and the brand, product and/or service actual performance (Calvo-Porral \& Lévy-Mangin, 2017). This way, this study contributes to reinforcing previous researches findings, supporting that brand awareness is a central aspect to influence perceived quality (H1: BRAND_AWAR $\rightarrow$ PERC_QUA) (Rubio et al., 2014; Sasmita \& Suki, 2015).

Another important factor that can affect brand awareness and perceived quality is related to brand personality congruence with the consumer agent, that is, with the set of human features associated to the brand and its customer profile (H2: BRAND_PERS $\rightarrow$ BRAND_AWAR, and H3: BRAND_ PERS $\rightarrow$ PERC_QUA). This means that the greater the identification of the characteristic traits of a brand, the greater will the recognition or remembering brand capacity by the customer be, and also the greater the disposition to realize its inherent qualities (Su \& Tong, 2015).

Besides, brand personality can be a strong tie to build substantial emotional relationships with customers (Aaker, 1996; Aaker, Vohs, \& Mogilner, 
2010; Roy et al., 2016), as for example brand love and its consequent brand loyalty formation. In this sense, as supposed, brand personality effect over brand love emerges, which has demonstrated to be significant (H4: BRAND_ PERS $\rightarrow$ BRAND_LOVE).

Another contribution of the present study is the confirmation of $\mathrm{H} 5$ (BRAND_LOVE $\rightarrow$ BRAND_LOYAL), which denoted that brand love positively influences brand loyalty in the customer perspective. Corroborating with this evidence, recent researches demonstrate expressive results of the customer emotional ties in relation to a specific brand and, this way, it is ratified that stronger emotional ties with the brand (brand love) evidence greater degree of brand loyalty from customers (Kaufmann et al., 2016; Hegner et al., 2017).

In the contemporary context, competition is each time more evident in a global scale, therefore, consolidating a strong brand can reduce market risk and help companies' sustainability in the long term and in a scenario in which markets are characterized as highly competitive (Kumar \& Patra, 2017).

First, it is highlighted that the implications extracted here reinforce the idea that a strong brand-building investment is one of the most important that a company can effect and, naturally, represents one of the most valuable assets for any company. Besides, the results attest that both the emotional elements (intangibles) and the functional elements (tangibles) develop an important role in building a range of customers loyal to the brand. In other words, customers when choosing a brand can seek not just for functional benefits from the interaction with it, but also emotional and affective benefits.

That said, it is emphasized this study's managerial implications contribution, which contributes to delineating organizations strategies, not mentioning that they can increase market share, recognizing the importance of sustaining the investments to foment customers brand loyalty; always realizing that this range of customers will be the brands frequent buyers and will be more prone to resist to situational factors and marketing efforts from the competition.

Another aspect to be considered by managers is the color and symbolism associated with the brand. In a unique way, considering this investigation's study object, due to the fact that Guaraná Jesus brand has a rosy tone and a sweet taste with a touch of cloves and cinnamon, giving an exotic value to the product/brand, managers can explore these elements as character traits of the exciting dimension. In addition, design and packaging aspects may provide, in addition to the distinctive capacity in the market associated with brand recognition, a convergence with traits of excitement, reliability or 
even robustness for the customer. From this angle, when customers are inspired by a modern and sophisticated design and involved as part of this process, they begin to demonstrate the excitement, the enthusiasm, the characteristics of the product, and begin to consider the brand as reliable and safe.

It also is verified that customers that show brand love for a given brand tend not to just repurchase it but also to promote it for friends and family, and also feel distressed when not using it, making companies obtain financial gains (revenue, profit) in the long term. Due to this fact, managers should focus their attention not just to the utilitarian aspects of transactional exchanges inherent to the brand, product and/or service, but, specifically, to the behavioral aspects attached to customers' desires, emotions and feelings, to multisensory elements, consumption experiences, mainly the ones connected to hedonic consumption.

In this logic, organizations that develop the ability to make customers love their brands can more easily encourage them to spread positive word-ofmouth (Anggraeni \& Rachmanita, 2015), both in the traditional and in the electronic context. Briefly, it is suggested to managers to recognize the importance of these arguments and the power of brand positioning, considering the cognitive and emotional aspects as a means to establish strong ties with customers, since it may be a solid basis to generate brand loyalty, and provide greater profitability, return and sustainability for the organization in the long term.

This study contributes to brand management literature, specifically by approaching brand loyalty determinants. However, it is considered that there was not research possibilities exhaustion. That said, it is suggested this study replication to another sample, or research context, for different brands (hedonic and/or utilitarian), in the same product and/or service category or in different ones, aiming at comparing results.

In a second moment, considering that other constructs, as example of brand experience, brand prestige, commitment to the brand, brand image, brand attachment, and purchase intention, besides customer involvement with the product or brand and perceived value, could be considered brand loyalty determinants, verifying alternate models that can have greater explanation power. Due to the exposed, future research opportunities are identified considering such possibilities, which could enrich the proposed and validated theoretical model or compose nested models or rival models. And given the multidimensional nature of the concept of brand loyalty, it is believed that its evaluation with two-dimensional or multidimensional 
scales could capture other facets of customer interaction with the brand, which could promote new analysis perspectives, both with approaches like the one used in the research (structural equation modeling), and experimental studies implementation.

\section{DETERMINANTES DA LEALDADE À MARCA NO CONTEXTO DE UMA MARCA DE REFRIGERANTE}

\section{RESUMO}

Objetivo: Desenvolver e manter a lealdade dos consumidores em relação à marca é requisito estratégico para negócios bem-sucedidos. Nesse sentido, o presente estudo teve por objetivo analisar o impacto de alguns construtos determinantes da lealdade à marca.

Originalidade/valor: Exploramos a qualidade percebida, a conscientização da marca, a personalidade da marca e o amor à marca como determinantes da lealdade à marca. Nesse sentido, o foco deste estudo foi analisar o impacto de alguns construtos determinantes da lealdade à marca.

Design/metodologia/abordagem: O estudo foi implementado por meio de uma pesquisa do tipo survey, aplicada a uma amostra de 284 consumidores de uma marca de refrigerante do Nordeste do Brasil adquirida por um dos maiores fabricantes de refrigerante do mundo. Os dados foram analisados utilizando-se estatísticas multivariadas e mediante o emprego da técnica de modelagem de equações estruturais.

Resultados: Foi possível concluir, então, que há uma relação positiva entre os construtos consciência da marca e qualidade percebida, e a influência positiva da personalidade da marca na consciência da marca e da qualidade percebida no amor à marca. Obtiveram-se ainda evidências que mostram que o amor à marca tem influência sobre a lealdade à marca $\mathrm{e}$ que o nível de consumo é um moderador significativo dessa relação.

\section{PALAVRAS-CHAVE}

Qualidade percebida. Consciência da marca. Personalidade da marca. Amor à marca. Lealdade à marca. 


\section{REFERENCES}

Aaker, D. A. (1996). Measuring brand equity across products and markets. California Management Review, 38(3), 102-120.

Aaker, J. L. (1997). Dimensions of brand personality. Journal of Marketing Research, 34(3), 347-356. doi:10.1177/002224379703400304

Aaker, J., Vohs, K. D., \& Mogilner, C. (2010). Nonprofits are seen as warm and for-profits as competent: Firm stereotypes matter. The Journal of Consumer Research, 37(2), 224-237. doi:10.1086/651566

Aggarwal, P., \& McGill, A. (2012). When brands seem human, do humans act like brands? Automatic behavioral priming effects of brand anthropomorphism. Journal of Consumer Research, 39(2), 307-321. doi:10.1086/662614

Ahamd, A., \& Thyagaraj, K. S. (2014). Brand personality and brand equity research: Past developments and future directions the IUP. Journal of Brand Management, 11(3), 19-56.

Ahmad, A., \& Thyagaraj, K. S. (2017). An empirical comparison of two brand personality scales: Evidence from India. Journal of Retailing and Consumer Services, 36(1), 86-92. doi:10.1016/j.jretconser.2017.01.006

Ahn, K., Lee, J., \& Jeon, J. (2009). The effects of luxury brand-self identification on brand attachment and brand commitment: The moderating role of regulatory focus. Korean Marketing Journal, 19(4), 1-34.

Akdeniz, M. B., Calantone, R. J., \& Voorhees, C. M. (2014). Signaling quality: An examination of the effects of marketing and nonmarketing-controlled signals on perceptions of automotive brand quality. Journal of Product Innovation Management, 31(4), 728-743. doi:10.1111/jpim.12120

Albert, N., \& Merunka, D. (2013). The role of brand love in consumer-brand relationships. Journal of Consumer Marketing, 30(3), 258-266. doi:10.1108/ 07363761311328928

Albert, N., Merunka, D., \& Valette-Florence, P. (2013). Brand passion: Antecedents and consequences. Journal of Business Research, 66 (7), 904-909. doi:10.1016/j.jbusres.2011.12.009

Alloza, A. (2008). Brand engagement and brand experience at BBVA: The transformation of a 150 years old company. Corporate Reputation Review, 11, 371-379.

American Marketing Association (2017). Site institucional. Recuperado de https://www.ama.org/publications/MarketingNews/Pages/what-drivesbrand-loyalists.aspx 
Anggraeni, A., \& Rachmanita, R. E. (2015). Effects of brand love, personality and image on word of mouth: The case of local fashion brands among young consumers. Procedia Social and Behavioral Sciences, 211, 442-447. doi:10.1016/j.sbspro.2015.11.058

Apaydin, F., \& Köksal, M. E. (2011). Turkish consumers risk perception towards global computer brands. International Journal of Marketing Studies, 3(3), 165-173.

Bagozzi, R. P., \& Yi, Y. (2012). Specification, evaluation, and interpretation of structural equation models. Journal of the Academy of Marketing Science, 40(1), 8-34.

Bairrada, C. M., Coelho, F., \& Coelho, A. (2018). Antecedents and outcomes of brand love: Utilitarian and symbolic brand qualities. European Journal of Marketing, 52 (3/4), 656-682. doi:10.1108/EJM-02-2016-0081

Beldona, S., \& Wysong, S. (2007). Putting the "brand" back into store brands: An exploratory examination of store brands and brand personality. Journal of Product \& Brand Management, 16, 226-235. doi:10.1108/1061042 0710763912

Belk, R. W., \& Tumbat, G. (2005). The cult of Macintosh. Consumption, Markets and Culture, 8(3), 205-217. doi:10.1080/10253860500160403

Borzooei, M., \& Asgari, M. H. (2013). Branding and purchase intention: A brand personality appeal perspective. International Journal of Business and Management Invention, 2(8), 23-27.

Bouhlel, O., Mzoughi, N., Hadiji D., \& Ben, I. (2009). Slimane brand personality and mobile marketing: An empirical investigation world academy of science. Engineering and Technology, 53, 703-710.

Burns, R. B. (1986). The self-concept (4th ed.). London: Longman.

Byrne, B. M. (2016). Structural equation modeling with AMOS: Basic concepts, applications, and programming (3rd ed.). New York: Routledge.

Calvo-Porral, C., \& Lévy-Mangin, J. P. (2017). Store brands' purchase intention: Examining the role of perceived quality. European Research on Management and Business Economics, 23(2), 90-95. doi:10.1016/j.iedeen. 2016.10.001

Carroll, B. A., \& Ahuvia, A. C. (2006). Some antecedents and outcomes of brand love. Marketing Letters, 17(2), 79-89.

Chang, H. J., \& Jai, T. C. (2015). Is fast fashion sustainable? The effect of positioning strategies on consumers' attitudes and purchase intentions. Social Responsibility Journal, 11 (4), 853-867. doi:10.1108/SRJ-07-2014-0095 
Chi, H. K., Yeh, H. R., \& Yang, Y. T. (2009). The impact of brand awareness on consumer purchase intention: The mediating effect of perceived quality and brand loyalty. The Journal of International Management Studies, 4(1), 135-144.

Chinomona, R. (2016). Brand communication, brand image and brand trust as antecedents of brand loyalty in Gauteng Province of South Africa. African Journal of Economic and Management Studies, 7(1), 124-139. doi:10.1108/ AJEMS-03-2013-0031

Chung, Y. J., Lee, J., \& Heath, L. R. (2013). Public relations aspects of brand attitudes and customer activity. Public Relations Review, 39(5), 432-439. doi:10.1016/j.pubrev.2013.05.001

Clemenz, J., Brettel, M., \& Moeller, T. (2012). How the personality of a brand impacts the perception of different dimensions of quality. Journal of Brand Management, 20(1), 52-64.

Dagger, T. S., \& David, M. E. (2012). Uncovering the real effect of switching costs on the satisfaction-loyalty association: The critical role of involvement and relationship benefits. European Journal of Marketing, 46(3), 447-468.

Das, G. (2016). Antecedents and consequences of trust: An e-tail branding perspective. International Journal of Retail \& Distribution Management, 44(7), 713-730. doi:10.1108/IJRDM-06-2015-0089

Davey, A., \& Savla, J. (2010). Statistical power analysis with missing data: A structural equation modeling approach. New York: Routledge.

Drennan, J., Bianchi, C., Cacho-Elizondo, S., Loureiro, S., Guibert, N., \& Proud, W. (2015). Examining the role of wine brand love on brand loyalty: A multi-country comparison International Journal of Hospitality Management, 49, 47-55. doi:10.1016/j.ijhm.2015.04.012

Emari, H., Jafari, A., \& Mogaddam, M. (2012). The mediatory impact of brand loyalty and brand image on brand equity. African Journal of Business Management, 6(17), 5692-5701. doi: 10.5897/AJBM11.788

Erdogmus, I., \& Büdeyri-Turan, I. (2012). The role of personality congruence, perceived quality, and prestige on ready-to-wear brand loyalty. Journal of Fashion Marketing and Management: An International Journal, 16(4), 399-417. doi:10.1108/13612021211265818

Fink, A. (2013). How to conduct surveys: A step-by-step guide (5th ed.). Thousand Oaks: Sage.

Fornell, C., \& Larcker, D. F. (1981). Evaluating structural equation models with unobservable variables and measurement error. Journal of Marketing Research, 18(1), 39-50. doi:10.1177/002224378101800104 
Giovanis, A. (2016). Consumer-brand relationships' development in the mobile internet market: Evidence from an extended relationship commitment paradigm. Journal of Product \& Brand Management, 25(6), 568-585. doi:10.1108/JPBM-05-2015-0884

Gordon, R., Zainuddin, N., \& Magee, C. (2016). Unlocking the potential of branding in social marketing services: Utilising brand personality and brand personality appeal. Journal of Services Marketing, 30(1), 48-62. doi:10. 1108/JSM-02-2015-0105

Grubor, A., Djokic, I., \& Milovanov, O. (2017). The influence of social media communication on brand equity: The evidence for environmentally friendly products. Applied Ecology and Environmental Research, 15(3), 963-983.

Ha, H. Y., \& Janda, S. (2014). Brand personality and its outcomes in the Chinese automobile industry. Asia Pacific Business Review, 20(2), 216-230. doi:10.1080/13602381.2013.841022

Hair, J. F., Jr., Black, W. C., Babin, B. J., \& Anderson, R. E. (2010). Multivariate data analysis (7th ed.). New York: Prentice Hall.

He, H., Li, Y., \& Harris, L. (2012). Social identity perspective on brand loyalty. Journal of Business Research, 65(5), 648-657. doi:10.1016/j.jbusres. 2011.03.007

Heding, T., Knudtzen, C. F., \& Bjerre, M. (2009). Brand management: Research, theory and practice. London: Routledge.

Hegner, S. M., Fenko, A., \& Teravesy, A. (2017). Using the theory of planned behaviour to understand brand love. Journal of Product \& Brand Management, 26(1), 26-41. doi:10.1108/JPBM-06-2016-1215

Huang, R., \& Sarigollu, E. (2011). How brand awareness relates to market outcome, brand equity, and the marketing mix. Journal of Business Research, 65(1), 92-99.

Instituto Brasileiro de Geografia e Estatística (2018). Dados socioeconômicos e demográficos. Recuperado de https://cidades.ibge.gov.br/brasil/ma/ panorama

Kan, W. (2002). The study of relation between product value, brand trust, brand affect and brand loyalty. Master Thesis, Tamkang University, Taiwan.

Kaufmann, H. R., Loureiro S. M. C., Basile, G., \& Vrontis, D. (2012). The increasing dynamics between consumers, social groups and brands. Qualitative Market Research: An International Journal, 15(4), 404-419. doi:10. 1108/13522751211257088 
Kaufmann, H. R., Loureiro S. M. C., \& Manarioti, A. (2016). Exploring behavioural branding, brand love and brand co-creation. Journal of Product \& Brand Management, 25(6), 516-526. doi:10.1108/JPBM-06-2015-0919

Kavaratzis, M., \& Hatch, M. J. (2013). The dynamics of place branding: An identity-based approach to place branding theory. Marketing Theory, 13, 69-86. doi:10.1177/1470593112467268

Keller, K. L. (1993). Conceptualizing, measuring and managing customerbased brand equity. Journal of Marketing, 57, 1-22. doi:10.1177/0022242 99305700101

Keller, K. L. (2003). Brand synthesis: The multidimensionality of brand knowledge.JournalofConsumerResearch,29(4),595-600.doi:10.1086/346254

Keller, K. L. (2008). Strategic brand management: Building, measuring, and managing brand equity (3rd ed.). Upper Saddle River: Prentice Hall.

Khan, I., \& Rahman, Z. A. (2016). Retail brand experience: Scale development and validation. Journal of Product $\mathcal{E}$ Brand Management, 25(5), 435-431.

Khan, I., Rahman, Z., \& Fatma, M. (2016). The role of customer brand engagement and brand experience in online banking. International Journal of Bank Marketing, 34(7), 1025-1041. doi:10.1108/IJBM-07-2015-0110

Kline, R. B. (2011). Principles and practice of structural equation modeling (3rd ed.). New York: The Guilford Press.

Kumar, S., \& Patra, S. (2017). Does promotion mix really help to enhance brand equity: A literature review Indian. Journal of Commerce \& Management Studies, 3(2), 80-86. doi:10.5958/2321-5763.2017.00211.6

Lee, H., \& Jee, Y. (2016). The impacts of brand asset of domestic screen golf playing systems upon brand trust and brand loyalty. International Journal of Sports Marketing and Sponsorship, 17(4), 320-332. doi:10.1108/IJSMS-112016-021

Limpasirisuwan, N., \& Donkwa, K. (2017). A structural equation model for enhancing. International Journal of Behavioral Science, 12 (1), 95-110.

Loureiro, S. M. C. (2013). The effect of perceived benefits, trust, quality, brand awareness/associations and brand loyalty on internet banking brand equity. International Journal of Electronic Commerce Studies, 4(2), 139-158. doi:10.7903/ijecs.1000

Loureiro, S. M. C., Kaufmann, H. R., \& Demetris, V. (2012). Brand emotional connection and loyalty. Journal of Brand Management, 20(1), 13-27.

Lu, L., Chang, W., \& Chang, H. (2014). Consumer attitudes toward blogger's sponsored recommendations and purchase intention: The effect of sponsorship type, product type, and brand awareness. Computers in Human Behavior, 34, 258-266. doi:10.1016/j.chb.2014.02.007 
MacCraken, G. (1989). Who is the celebrity endorser? Cultural foundations of the endorsement process. Journal of Consumer Research, 16(3), 310-321. doi: $10.1086 / 209217$

Maehle, N., \& Shneor, R. (2010). On congruence between brand and human personalities. Journal of Product \& Brand Management, 19(1), 44-53. doi:10. 1108/10610421011018383

Malär, L., Krohmer, H., Hoyer, W. D., \& Nyffenegger, B. (2011). Emotional brand attachment and brand personality: The relative importance of the actual and the ideal self. Journal of Marketing, 75(4), 35-52. doi:10.1509/ jmkg.75.4.35

Malhotra, N. K., Birks, D., \& Wills, P. (2012). Marketing research (4th ed.). New York: Pearson.

Moisescu, O. I., \& Allen, B. (2010).The relationship between the dimensions of brand loyalty: An empirical investigation among Romanian urban consumers. Management \& Marketing Challenges for Knowledge Society, 5(4), 83-98.

Molinillo, S., Japutra, A., Nguyen, B., \& Chen, C. S. (2017). Responsible brands vs active brands? An examination of brand personality on brand awareness, brand trust, and brand loyalty. Marketing Intelligence \& Planning, 35(2), 166-179. doi:10.1108/MIP-04-2016-0064

Nikhashemi R. S., Valaei, N., \& Tarofder, K. A. (2017). Does brand personality and perceived product quality play a major role in mobile phone consumers' switching behaviour? Global Business Review, 18(3), 1-20. doi:10.1177/ 0972150917693155

Pan, Y., Sheng, S., \& Xie, F. T. (2012). Antecedents of customer loyalty: An empirical synthesis and reexamination. Journal of Retailing and Consumer Services, 19(1), 150-158. doi:10.1016/j.jretconser.2011.11.004

Pappu, R., \& Quester, P. G. (2006). Does customer satisfaction lead to improved brand equity? An empirical examination of two categories of retail brands. Journal of Product \& Brand Management, 15(1), 4-14. doi:10.11 08/10610420610650837

Pappu, R., \& Quester, P. G. (2016). How does brand innovativeness affect brand loyalty? European Journal of Marketing, 50(1-2), 2-28. doi:10.1108/ EJM-01-2014-0020

Perera, W. L. M. V., \& Dissanayake, D. M. R. (2013). The impact of brand awareness, brand association and brand perceived quality on female consumers' purchase decision of foreign makeup products. International Conference on Business \& Information, Faculty of Commerce and Management Studies, University of Kelaniya, Sri Lanka. 
Phau, I., \& Lau, K. C. (2000). Brand personality and consumer selfexpression: Single or dual carriage away? Brand Management, 8(6), 428-444.

Pitta, D. A., \& Franzak, F. J. (2008). Foundations for building share of heart in global brands. Journal of Product \& Brand Management, 17(2), 64-72. doi:10.1108/10610420810864676

Prahalad, C. K., \& Ramaswamy, V. (2004). Co-creation experiences: The next practice in value creation. Journal of Interactive Marketing, 18(3), 5-14. doi:10.1002/dir.20015

Preacher, K. J., \& Hayes, A. F. (2004). SPSS and SAS procedures for estimating indirect effects in simple mediation models. Behavior Research Methods, Instruments, \& Computers, 36(4), 717-731.

Raska, D., \& Shaw, D. (2012). When is going green good for company image? Management Research Review, 35(3-4), 326-347. doi:10.1108/01409 171211210190

Rauschnabel, P. A., Krey, N., Babin, B. J., \& Ivens, B. S. (2016). Brand management in higher education: The University Brand Personality Scale. Journal of Business Research, 69(8), 3077-3086. doi:10.1016/j.jbusres.2016. 01.023

Rojas-Méndez, J. I., Murphy, S. A., \& Papadopoulos, N. (2013). The U. S. brand personality: A Sino perspective. Journal of Business Research, 66(8), 1028-1034. doi:10.1016/j.jbusres.2011.12.027

Roy, P., Khandeparkar, K., \& Motiani, M. (2016). A lovable personality: The effect of brand personality on brand love. Journal of Brand Management, 23(5), 97-113.

Rubio, N., Oubiña, J., \& Villaseñor, N. (2014). Brand awareness-brand quality inference and consumer's risk perception in store brands of food products. Food Quality \& Preference, 32, 289-298. doi:10.1016/j.foodqual. 2013.09.006

Sarkar, A. (2014). Brand love in emerging market: A qualitative investigation. Qualitative Market Research: An International Journal, 17(4), 481-494. doi:10. 1108/QMR-03-2013-0015

Sasmita, J., \& Suki, N. M. (2015). Young consumers' insights on brand equity. International Journal of Retail \& Distribution Management, 43(3), 276-292. doi:10.1108/IJRDM-02-2014-0024

Schultz, D. E., \& Block, M. P. (2015). Beyond brand loyalty: brand sustainability. Journal of Marketing Communications, 21 (5), 340-355. doi:10.1080/1 3527266.2013 .821227 
Sreejesh, S., Roy, S., \& Sarkar, A. (2016). Validating a scale to measure consumer's luxury brand aspiration. Journal of Product $\mathcal{E}$ Brand Management, 25(5), 465-478. doi:10.1108/JPBM-06-2014-0647

Su J., \& Tong, X. (2015). Brand personality and brand equity: Evidence from the sportswear industry. Journal of Product \& Brand Management, 24(2), 124-133. doi:10.1108/JPBM-01-2014-0482

Tabachnick, B. G., \& Fidell, L. S. (2012). Using multivariate statistics (6th ed.). Boston: Pearson.

Thaichon, P., \& Quach, T. N. (2015). From marketing communications to brand management: Factors influencing relationship quality and customer retention. Journal of Relationship Marketing, 14(3), 197-219. doi:10.1080/1 5332667.2015.1069523

Vera, J., \& Trujillo, A. (2017). Searching most influential variables to brand loyalty measurements: An exploratory study. Contaduría y Administración, 6 , 600-624. doi:10.1016/j.cya.2016.04.007

Won-Moo, H., Hanna, K., \& Joon, H. J. (2016). The role of gender differences in the impact of CSR perceptions on corporate marketing outcomes. Corporate Social Responsibility and Environmental Management, 23, 345-357. doi:10.1002/csr.1380

Wu, S. I., \& Chen, Y. J. (2014). The impact of green marketing and perceived innovation on purchase intention for green products. International Journal of Marketing Studies, 6(5), 81-100.

Wu, W., \& Anridho, N. (2016). The antecedents of brand loyalty: A metaanalysis study. International Journal of Services and Standards, 11 (3), 242-260. doi:10.1504/IJSS.2016.080048

Yoo, B., Donthu, N., \& Lee, S. (2000). An examination of selected marketing mix elements and brand equity. Journal of the Academy of Marketing Science, 28(2), 195-211. doi:10.1177/0092070300282002

Zainol, Z., Omar, N. A., Osman, J., \& Habidin, N. F. (2016). The effect of customer-brand relationship investments dimensions on customer engagement in emerging markets. Journal of Relationship Marketing, 15(3), 172-199. doi:10.1080/15332667.2016.1209051

Zeithaml, V. (1988). Consumer perceptions of price, quality and value: A means-end model and synthesis of evidence. Journal of Consumer Research, 52(3), 2-22. doi:10.1177/002224298805200302 


\section{AUTHOR NOTES}

Valter M. M. Fortes, Programa de Pós-Graduação em Administração, Universidade de Caxias do Sul (UCS); Gabriel S. Milan, Departamento de Administração, Universidade Federal do Rio Grande do Sul (UFRGS); Luciene Eberle, Programa de Pós-Graduação em Administração, Pontifícia Universidade Católica do Rio Grande do Sul (PUCRS); and Deonir De Toni, Programa de Pós-Graduação em Administração, Universidade Federal do Rio Grande do Sul (UFRGS).

Valter M. M. Fortes is now freelance consultant; Gabriel S. Milan is now professor at Programa de Pós-Graduação em Gestão e Negócios at Universidade do Vale do Rio dos Sinos (Unisinos); Luciene Eberle is now professor and reseacher at Postgraduate Program in Administration at Universidade Caxias do Sul (UCS); and Deonir De Toni is now professor and reseacher at Postgraduate Program in Administration at Universidade Caxias do Sul (UCS).

Correspondence concerning this article should be addressed to Valter M. M. Fortes, Rua Sinimbu, 1670, Center, Caxias do Sul, Rio Grande do Sul, Brazil, CEP 95020-001.

E-mail: valter.fortes1@gmail.com

EDITORIAL BOARD

Editors-in-chief

Janette Brunstein

Silvia Marcia Russi de Domênico

Associated Editor

Gisela Demo

Technical Support

Vitória Batista Santos Silva

\section{EDITORIAL PRODUCTION}

Publishing Coordination

Jéssica Dametta

Language Editor

Daniel de Almeida Leão

\section{Layout Designer}

Emap

Graphic Designer

Libro 